\title{
Natural resources management to deliver Sustainable Development Goals (SDGs)
}

\section{Wahyu Widiyono}

Botany Division, Research Center for Biology, Gibinong Science Center, The Indonesian Institute of Sciences, JL. Raya Jakarta-Bogor, Km. 46, Cibinong-Indonesia

Corresponding author:wahyu_widiyono@yahoo.com

\begin{abstract}
Indonesia is known as a rich natural resources country, but at the same time has a problem of water shortage, soil degradation, pollution, agriculture and forest production, biodiversity conservation, and mineral and energy sustainability. The national natural resources management planning alignment with SDGs programme, particularly the water resources management, afforestation programme, a guide for sustainable management of Indonesia's biodiversity, government and non-government organizations participant in conservation practice, exploring alternative energy sources to reduce dependence on oil, mainstreaming of SDGs into National Development agenda, National Action Plan, and SDGs program for Sub-national level. This program was participated by all stakeholders included government, civil society organizations, philanthropy and business society, academics as well as experts. This literature review paper will discuss about the natural resources management to deliver sustainable development goals programme in Indonesian, with specific and focus topics for water and pollution, soil, land product (agriculture, forest and biological resources), mineral and energy. The objective of this paper was to describe the alignment of the natural resources management planning and SDGs programme as evaluation to improve their implementation in Indonesia. Though the government has already implemented SDGs program but innovative strategic need to be developed.
\end{abstract}

\begin{abstract}
ABSTRAK
Indonesia dikenal sebagai negara yang kaya sumberdaya alam, tetapi pada saat yang sama menghadapi masalah kelangkaan air, degradasi lahan, polusi, produksi pertanian dan kehutanan, konservasi keanekaragaman hayati, keberlangsungan mineral dan energi. Rencana pengelolaan sumberdaya alam nasional sejalan dengan program SDGs, khususnya terkait pengelolaan air, program perhutanian, pengelolaan keanekaragaman hayati secara berkelanjutan, pemerintah dan para pihak yang berpartisipasi dalam praktek konservasi, eksplorasi energi alternatif untuk mengurangi ketergantungan pada minyak bumi, dan pengarus-utamakaan program SDGs ke dalam agenda pembangunan nasional, rencana aksi nasional, dan program di tingkat wilayah. Program ini diikuti oleh seluruh para pihak, termasuk pemerintah, organisasi masyarakat sipil, masyarakat bisnis dan filantropi, kaum akademisi dan para ahli. Studi Pustaka ini akan membahas tentang pengelolaan sumberdaya alam untuk mencapai program pembangunan berkelanjutan di Indonesia, khususnya tentang masalah air, polusi, produsi lahan (meliputi pertanian, hutan, sumberdaya biologi), mineral dan energi. Tujuan penulisan naskah adalah untuk memberikan gambaran keterkaitan antara rencana pengelolaan sumberdaya alam dan pelaksanaan program pembangunan berkelanjutan, sebagai evaluasi untuk meningkatkan implementasinya di Indonesia. Meskipun pemerintah telah melaksanakan program SDGs, tetapi strategi yang inovatif perlu dikembangkan.
\end{abstract}

Keywords: Natural resources, management, SDGs, environment

\section{INTRODUGTION}

Natural resources degradation are serious problem that was taken place in Indonesia and in the world. This problems were exaggerated by the rapid population increase, the excessive consumption of resources, and pollution. The abundant resources of Indonesia are blessing, but at the same time will become disaster if they are not managed wisely.

Indonesia is known as a strategic geographic and rich natural resources country. Indonesia, located between the Pacific Ocean and the Indian Ocean in Southeast Asia has 735.358 square miles area that spread out in over 13.000 islands, with population was estimated 261 million people (Sawe, 2018). The fertile soil, abundant water, and humid climate support the

Submitted 22 July 2020; Accepted 23 September 2020 tropical rain forest and biodiversity.

Indonesia contains the most extensive standing rainforests in all of Asia, with an estimated 94 million hectares (232 million acres) of forest cover - an area the size of Nigeria. These trees release oxygen into the air and remove harmful particles. They also absorb gases, like carbon dioxide, that cause changes in our climate. Flora and fauna also attracted the visitors from across the world flock to Indonesia to see its charismatic native species - such as orangutans, Sumatran tigers, Komodo dragons, whale sharks, sea turtles and manta rays. The country's incredible rainforests and coral reefs make it one of the top adventure and dive destinations in the world. Indonesia's lands and waters make the country a major producer of foods that 
Indonesians, as well as people around the world, eat every day: seafood, rice, coffee, cocoa, cassava, peanuts and spices like nutmeg. It is also the world's largest producer of palm oil, an edible vegetable oil found in half of the packaged goods on supermarket shelves (Conservation International Indonesia, 2020). Indonesia also has abundant of natural resources, such as potential deposit hydrographic, mineral and energy.

However, Indonesia has a big problem concerning to increase population very quickly. Despite being blessed with abundant amounts of natural resources, about $11.2 \%$ of Indonesia's population lives below the poverty line. Academics around the world studying similar phenomenon across the world in resource-rich countries call this the "natural resource phenomenon." The phenomenon describes the contradictory relationship between a nation's economic performances compared to natural resource wealth. One of the primary contributors to this unique phenomenon is what economists refer to as the "Dutch disease," a phenomenon where the development of a specific sector leads to the decline of other sectors (Sawe, 2018). The country's response to this development will determine the fate of its abundant natural wealth - and the people who depend on it.

The Sustainable Development Goals (SDGs) were conceived at the United Nations Conference on Sustainable Development in 2012, as a set of universal goals designed to expand on the Millennium Development Goals which had been created to confront the environmental, economic, and political challenges facing the world at the end of the 20th century. The roots of the two sets of goals can be traced back to the 1970s and 1980s when, amid increasing concerns about environmental degradation, nations became more aware of the importance of protecting the environment while continuing to follow an economic and social development agenda both nationally and globally (WCED, 1987).

Indonesia was very committed to succeed SDGs programme, that include (1) Social development including poverty reduction and hunger, health, education and gender equity; (2) Economic development including clean and affordable energy, decent work and economic growth, innovation, industry and infrastructure, reduce inequality, and partnership; (3) Environmental development including clean water and sanitation, sustainable cities and communities, responsible consumption and production, climate action, life below water and life on land. The programme was started focuses on achievement in health, food security, sustainable agriculture and education, while the latter focuses on industrial development, innovation, infrastructure, and protection and sustainable use of marine and coastal ecosystem. This literature review paper will discuss about the natural resources management to deliver SDGs programme in Indonesian, with specific and focus topics for water and pollution, soil, land product (agriculture, forest and biological resources), mineral and energy. Aim of paper was to describe the alignment of the natural resources management planning and SDGs programme as evaluation to improve their implementation in Indonesia.

\section{RESULTS AND DISGUSSION}

The results and discussion will be divided in the three part, were (1) natural resources potential, (2) natural resources management, and (3) implementation of SDGs programme in Indonesia.

\section{Natural Resources Potential}

The potential natural resources in Indonesia can be classified as (1) inexhaustible resources with the case study of water and pollution; and (2) exhaustible resources that divided by (a) renewable exhaustible resources with case study of soil, product of land (agriculture, forest and biological resources), and (b) non-renewable exhaustible resources with case study of mineral and energy (Owen, 1985).

\section{Water}

Despite of the abundance of water resources potential, the Indonesia's surface water resources have already experienced water shortage during the dry season. The total water demand of the country is currently $1,074 \mathrm{~m}^{-3} \mathrm{sec}^{-1}$ for irrigation, domestic, municipal and industrial purposes, while the low flow available at the normal climatic year is only about 790 $\mathrm{m}^{-3} \mathrm{sec}^{-1}$. This explains that the current water uses is highly constrained by unbalanced condition of demands and the potential availability of water, particularly at point of time during the season of scarcity of the year. Indonesia's population of 207,6 million (2000) is spread over a number of islands. The increasing population in Indonesia is not followed by the equal distribution of population regionally either by province or by island. According to 2000 Population Census, Java Island resided by around $59 \%$ of population, which has area of $7 \%$ to total area of Indonesia. Meanwhile, Maluku and Papua have 25\% of the total area of Indonesia but are inhabited by $2 \%$ total Indonesian population. With the current growth rate of $1.66 \%$ the population is expected to grow to 280 million by the year 2020. In the past decade urban immigration has resulted in an urban growth of about $5 \%$ annually. It is estimated, therefore that by the year 2020 about $52 \%$ of the nation's population will live in urban surroundings, compared to 38\% in 1995 (World Water Council, 2003).

Though precipitation daily sound, like a lot; nevertheless, a severe water shortage is the most urgent, long-range, environment problem facing some nations in the world (Ja"germeyr et al., 2017). Water was related to issues of floods, droughts, soil erosion and 
sludge production, lack of adequate water storage, watersheds degradation, threats on water availability and sustainability, water quality problems (Fulazzaky, 2014).

\section{Pollution}

Pollution can be taken place in the atmosphere, in the soil and water. Major atmospheric pollutants can be a carbon monoxide (CO), oxides of sulfur, hydrocarbons, particulate matter, oxydes of nitrogen, photochemical smog and ozone; Sources of pollutants can come from transportation and industry; Air pollution indirectly effect to climate change. One harmful aspect of air pollution is that it may directly modify the intensity of sunlight, temperature, cloud formation, and the distribution volume, and acidity of rainfall. Moreover, relatively slight rainfall or temperature changes may disrupt the balance of ecosystems by eliminating key plant and animal species.

Anorganic pesticide pollutant effect seriously to ecosystem stability. Some field receive heavy pesticide dosage of solid or solute waste. Solid waste, such as wastepaper, can, bottles, junked cars, tires, plastic and so on. Industrial hazard was can serious effect to groundwater and surface water problem. In undisturbed ecosystems there exist naturally occurring regulatory mechanisms, that keep population levels of a species at a point of equilibrium. However, whenever the original ecosystem becomes restructured by humans, it tends to become simplified, with a resultant disruption of the stabilizing influences of density-dependent regulatory factors. A lot of human intervention that tend to simplify the ecosystem.

\section{Soil}

Indonesia mainland has variety of soils, parent materials, landforms, elevations and climates. This condition is the main capitals to produce sustainable agricultural commodities. The utilization of land resources to develop agriculture should consider its potentials in gaining the optimum results. Up to now the agricultural area used for agricultural purposes cover 70.2 million hectares consisting of rice field, upland crop field, yard, plantation, grazing land, trees, and fish pond. Based on the assessment results by Indonesian Agency for Agricultural Research and Development, the land in Indonesia which is potential or suitable for agriculture covers 94 million hectares, comprising 25.4 million hectares of wetland (rice field) and 68.6 million hectares of upland/dryland. There are 30.67 million hectares of the total area which is potential for agricultural extensification comprising of 8.28 million hectares annual wetland agriculture (rice field), 7.08 million hectares annual upland agriculture, and 15.31 million hectares perennial agriculture. Wetland for annual crops covers swampy land with the total of 2.98 million hectares (mainly in Papua) and non swampy land 5.30 million hectares. In Indonesia the potential land as well as available land for agricultural extensification is still sufficient, but by the increasing needs of land for agriculture and non-agriculture, careful utilization is needed. The landuse competition in the future as a consequences to keep national food security and develop bioenergy needs to be overcome. Some efforts that can be done are by increasing the productivity (intensification), correct landuse based-extensification, and developing primary technological innovation (Hidayat, 2009).

Soil role as habitat of micro and macro-organism. The living community of soil organism includes bacteria, molds, protozoa, mites, insect larvae, millipedes, earthworms, burrowing mammals (moles), and so on. The environment with which this soil community interacts is composed of trillions of rock particles, detritus (decaying organic matter), water, gases (oxygen, carbon dioxide, etc.), chemical energy, heat energy, and so on (Rasul, 2016). The activity of living organisms play an important role in soil development. The soil, in turn, is an important factor in the distribution of both plants and animals.

\section{Product of land}

Agriculture. As an agricultural country, agriculture became the most important livelihood for the majority of the people of Indonesia. Agricultural land area approximately $82,71 \%$ of the total land area. The land is mainly used for rice cultivation. The spread of rice production is still concentrated in Java due to the high productivity and harvested area compared to other islands. Other agricultural production are maize, sweet potatoes, peanuts and soybeans. The production of vegetables, horticultural species include large red onion, scallion, potato, cabbage and carrots. While the production of horticultural types of fruits include mango, durian, oranges, bananas, papaya and barking. Based on the age of plants, plantations in Indonesia is divided into two major groups, namely crops (sugarcane, tobacco, cotton, distance, fragrant lemongrass, patchouli and hemp) and perennial crops (rubber, coconut, coffee, palm oil, clove, nutmeg, wood sweet, vanilla, hazelnut, nut, tamarind, palm, palm, coconut, and sago palm). Most of the plantation cultivation of annual crops (Rio, 2012). Livestock population in Indonesia consists of a large livestock population, such as dairy cows, beef cattle, buffalo, and horses. Population of small ruminants include: goats, sheep, and pigs. While the poultry population consisted of chicken, broiler chicken, broiler chickens and ducks. Among livestock products, which currently has export prospects are processed leather (tanned).

Forest. Based on the function, Indonesia's forests are divided into four types, namely protected forest, production forest, nature reserves, and forest tours. Forestry production in the form of forest wood, well logs, sawn timber and plywood. From the results of these forests, which is currently a mainstay product 
Indonesia for export activity is plywood. Physical fact that two-thirds of Indonesia in the form of the sea, the sea's natural resources have huge potential. In addition to containing oil, gas, mineral and marine non-conventional energy, and treasure that has begun to be dug though still limited, the sea also produces fish is estimated at 6,4 million tons per year. Currently the only used about $70 \%$. The development of marine resources and fisheries are grouped in five marine industry, namely the fishing industry, marine energy, mining and industry, maritime industry, including shipbuilding industry, shipping industry (marine transport) and the tourism industry (marine tourism and conservation areas). Today is a mainstay of Indonesian fishery exports are shrimp and tuna (Rio, 2012).

The nation also has the region's largest exploitable tropical forests namely in Papua and Kalimantan which support a healthy timber industry. The rainforests, which are the world's third largest, are home to 29,000 species of plants and 3,000 species of animals. The timber industry has witnessed steady growth since the 1960's with legitimate and illegal loggers targeting specific tree species such as Teak and Meranti which is in high demand due to its reddish easily workable wood that is also considerably lightweight. Vennes and plywood that is produced locally is either consumed locally or exported. The excessive exploitation of forests has led to massive deforestation and substantial environmental degradation. The rate of environmental degradation is further accelerated by government-sanctioned conversion of tracts of forest into agricultural fields (Sawe, 2018).

Biological resources. Indonesia's mega-biodiversity, consisted of Terrestrial area 1.860.359,67 km², Marine area 5,8 million $\mathrm{km}^{2}$, 33 Provinces, approx. 424 cities/districts, Population 218,9 millions (2005), Biodiversity: Mammals 515 species, Reptiles 781 species, Primates 35 species, Aves 1595 species, Amphibia 270 species, Plants (angiospermae, gymnospermae dan pteridophyta) 31,746 species (Nalang, 2003).

The population of any organism will be the result of the interaction of the two antagonistic forces of the environmental resistance (ER) and the biotic potential (BP). The population of an organism is controlled in part by density-independent factors, such as heat, cold, drought and so on; Habitat is the general environment in which an organism lives---its natural home. The habitat of a wild animal provides certain essentials: shelter, food, water, breeding sites (den, nest, or burrow), and a fairly well-defined area called territory, in which an animal has psychological dominance over intruders.

Tropical ecosystems provide a wide and complex range of goods and services to individuals and communities. Environmental valuation includes a diverse and complex set of values that can be conceptualized in a number of ways. Direct-use values: Resources for extraction, water services, recreation and tourism; Indirect-use values: Climate regulation, physical protection; Non-use values: Option value (i.e. willingness to pay), existence value (i.e. value of knowing the resource exits); Intrinsic values: Values not tied to human use. When ecosystems are destroyed or degraded, the impacts on natural resources, biodiversity and ecosystem services can represent huge losses to the state, society and individuals. These diverse environmental values include: direct-use values related to natural resources that can be managed and extracted (e.g. timber, minerals and non-timber forest products) and in direct use values associated with biodiversity and ecosystem services (e.g. hydrological, pollination and climate regulation services, recreation and tourism). Nature also holds intrinsic values and non-use cultural, religious and historical values. When ecosystems are destroyed or degraded, the impacts on natural resources, biodiversity and ecosystem services can represent huge losses to the state, society and individuals (Bryant, 2020; Phelps et al., 2014).

\section{Mineral and energy}

Unlike forest, wildlife, fisheries, and even soil, mineral resources are non-renewable exhaustible---they cannot be renewed once they are consumed. The great majority of minerals now used by society have been extracted from earth's crust. Good example are gold, silver, and diamond (carbon). Those mineral compounds are not distributed uniformly. Recently, gasoline supplies became so scarce that thousand of independent dealer throughout the world were force to stop pumping gas. The kind of energy resources are coal, coal gasification, coal liquefaction, oil, natural gas, oil shale, tar sands (Owen, 1985).

The various sources of energy can be conveniently grouped as commercial primary energy resources was included the non-renewable sources of energy or conventional sources of energy are being accumulated in nature for a very long time and can't be replaced if exhausted. Nature gifted resources which are consumed can't be replaced, e.g.: coal, petroleum, natural gas, thermal power, hydro power and nuclear power are the main conventional sources of energy; Renewable sources of energy was included of energy sources, which are continuously and freely produced in the nature and are not exhaustible are known as the renewable sources of energy, e.g.: solar energy, biomass and wood energy, geo thermal energy, wind energy, tidal energy and ocean energy (ICAR, 2020).

The mining sector is one of the largest industries in the country as vast exploited and un-prospected mineral deposits support it. The nation's mineral 
resource exports are dominated by natural gas and crude petroleum. Other major mineral exports include coal, nickel, bauxite, gold, tin, and copper. The country's industrial development is also to a large extent based on the domestic processing of mineral wealth. However, most of the minerals are exported in a raw or semi-processed state to some industrialized nations.

The Indonesian abundant natural resources above need to be managed efficiently in order to meet the need of social, economic and environment sustainably.

\section{Natural Resources Management}

\section{Water resources development}

The role Water Resources Development in Indonesia has been put by the ancient generation of Indonesian, highly importance. This had been supported by strong evidence for the case for agricultural water utilizations. This fact would likely remain constant and yet sustainable toward the long-term future. Water resources have played a major role in Indonesian development. Currently, over 5.5 million hectares of agricultural lands have been served with technical irrigation schemes. Parallel with these, another 1.6 million hectares are irrigated under the village irrigation schemes. These involved diversity of either construction or rehabilitation works of about 12,500 diversion structures and 40 reservoirs. Apart from these, Indonesia has also been able to extend water resources utilization progressively to support its 2,200 megawatts of hydropower generation -- which is now encompassed about 20 percent of the nation's electricity generating capacity. Rural and Urban water supply schemes deliver close to 100,000 litres per second of piped drinking water. On top of the above achievement, over 3.3 million out of the 3.4 million hectares of swamplands have been developed and major flood control and drainage projects have been implemented. In addition, nearly 18,000 hectares of fishponds have been developed mostly in Aceh, North Sumatra and Sulawesi. In addition, about 1.96 million hectares of lowlands and urban areas are provided with flood protection infrastructures, compounded with 15 kilometres of coastal structural protections (World Water Council, 2003).

The government of Indonesia has made special efforts on integrated water resources management (IWRM) since the enactment of Law No. 7/2004 on water resources. Guided by this law, the decision makers, managers and operators will always strive to do the right things to implement the strategies, programs and activities to support water management. The law and policies governing the implementation of IWRM are the legal provision for managing water resources in the river basin perspective but have not yet been synchronized effectively. Each ministry in pursuit of its mission has a mandate with responsibility for promoting social, economic, environmental and cultural well-being of communities in the present and for the future. Challenging the IWRM perspective may be the pilot projects need to be done together in order to solve a problem. This perspective seeks inter-ministerial cooperation and coordination to expedite clearances for water management activities. The goal of involvement different ministries is to help identify and implement mechanisms that encourage members to find ways to become involved in analyzing the complexity of implementation projects. Multi-criteria decision analysis is an umbrella approach that has been applied to a wide range of water management situations and helps to frame a group process that made stakeholder preferences explicit and substantive discussions about long-term river management possible (Fulazzaky, 2014).

\section{Soil management}

The establishment of plantation forest or natural regrowth was seen to decrease surface runoff and sediment generation and therefore, in principle, de-intensification can provide a solution to on-site and downstream sediment problems. Conventional fallow systems do not seem sustainable given the mounting population pressure, however. Fields are often left fallow for one or two years after three to five cropping seasons in order to regain some degree of fertility. These typically short fallow periods are too short for substantial soil restoration and fodder is often cut on such fields, favouring the establishment of grasses with low nutritional value such as Imperata cylindrica. Soil fertility may be restored to some extent by afforestation, depending on the species involved and the 'improved' fallow period. Albizia trees rapidly enhanced soil carbon and nitrogen contents, although the possible consequences for other soil nutrients (potassium, calcium, phosphorus) and soil acidity require more attention. Plantation forest can also provide income through the sale of timber and fuel wood after some years, but potential constraints to afforestation include the lack of rapid benefits, the tree stumps that impede tillage after clear-felling, and the possibility of pest outbreaks. The alternative is to try and simultaneously reduce environmental problems and enhance land productivity through intensification. Although promoted unsuccessfully in the study area in the past, intensification on rain-fed land through agro-forestry (involving fodder crops for stall-fed livestock) still seems viable (van Dijk et al., 2004).

Agriculture. The modern farm is a special type of ecosystem consisting of both natural and human-made components. We shall call it an agroecosystem. The structure of this ecosystem consists of both biotic (farmer, crops, insect pests, and so on) and abiotic (soil minerals, climate, solar energy, and fossil fuels) components which interact. The function of the agroecosystem includes such processes as: plowing, 
fertilizer application, photosynthesis, irrigation and soil erosion (Waldron et al., 2017). Unique nature of Indonesian geography, coupled with the lack of transport infrastructure, makes their exploitation challenging. Moreover, a lack of investment, protectionism and an unwieldy regulatory environment are all inhibiting the sector from reaching its full potential. Agriculture has been held back by low productivity, under-investment, unclear property rights on land, ill-advised trade regulations, misplaced support for staples and restrictions on foreign ownership. By pursuing crop diversification, encouraging co-operation between smallholders and large estates and easing constraints on foreign investment, Indonesia could raise its farmers' productivity.

Forest. The forest ecosystem is essentially a community of organisms, the member of which interact with the living and non-living components of this environment. A forest is a complex ecosystem. It is composed of both living (tress, herbs, shrubs, weeds, soil bacteria, fungi, viruses, earthworms, caterpillars, moths, bark beetles, grouse, bear, deer), and non living (water, rock, particles, solar radiation, wind, and so on) components; The forest management must always consider of ecological, social, and legal constraints factors.

Biodiversity and conservation. Conservation is state of harmony between man and the environment. They include the following: Preservation, preserving resources from human destruction; restoration, repairing the damage, so that the original value and productivity of the resource can be restored; beneficiation or upgrading a resource, upgrading of any natural resource such as forest, farmland or fishery; substitution, the replacement of a scarce resource with one that is more abundant; maximization, refer to the reduction of waste by the most efficient use of a resource that is possible; reusing ad recycling, the use and reuse of sewage -contaminated river water throughout urban area; integration, the determination of how to maximal value of such a complex of interrelated and interacting resources for society. Our complex and varied of natural environment are dynamic and organic whole. Humans cannot degrade one part of the environment without at the same time harming other parts as well.

A guide for sustainable management of Indonesia's biodiversity was mentioned in Indonesia Biodiversity Action Plan (IBSAP), in 1993. In IBSAP 2003 was formulated a participatory, bottom-up and transparent approach. The regional autonomy and decentralization, need to improve involvement of community in biodiversity management, shift biodiversity management paradigm, new strategy systems and action plan that is more contextual with the current situation (Nalang, 2009).

Management and conservation should be applied according to ecological approach principle. We have defined ecology as the study of the interrelationship that exist between organism and their environment. An understanding of certain basic ecological concept will aid in developing and appreciation not only of the problems facing the conservationist and environmentalist, but also of the policies, strategies,

Table 1. Major Natural Resources, Conservation Issues, Government responsible Agencies and Non-governmental organizations (Bryant, 2020).

\begin{tabular}{|c|c|}
\hline \multicolumn{2}{|r|}{ Indonesia } \\
\hline Location & Southeast Asia, archipelago between the Indian Ocean and the Pacific Ocean \\
\hline National Websites & Indonesian Government Links \\
\hline $\begin{array}{l}\text { Embassy / Chancery in } \\
\text { U.S. }\end{array}$ & 2020 Massachusetts Avenue NW Washington D.C. 20036 \\
\hline $\begin{array}{l}\text { Agencies responsible for } \\
\text { biological inventory and } \\
\text { conservation }\end{array}$ & Ministry of Forestry and Ministry of Environment \\
\hline $\begin{array}{l}\text { Non-governmental } \\
\text { organizations concerned } \\
\text { with conservation }\end{array}$ & $\begin{array}{l}\text { See "Professional Organization"World Wide Fund For Nature (WWF) Indonesia Programme The Nature Conservancy } \\
\text { (TNC) Indonesia Programme World Environment Center (WEC) Conservation Internasional (CI) Indonesia Programme } \\
\text { Care Internasional Indonesia Organization Industrial Spiritual and Culture Advancement (OISCA) Asia Westland } \\
\text { Bureau (AWB) Canadian University Service Overseas (CUSO) (The) Fort Wayne Zoological Society and Concervation } \\
\text { International (FWZS/CI) (The) International Council for Bird Preservation (ICBP) atau Birdlife Sticthing FACE (Forest } \\
\text { Absorbing Carbon dioxide Emission) Center For International Forestry Research (CIFOR) (The) Tropenbos Foundation } \\
\text { (The) International Crops Research Institute for (the) Semi Arid Tropics (ICRISAT) (The) Gottingen University Centre } \\
\text { de Cooperation Internationale en Recherche Agronomique Pour le Development (CIRAD) (The) International Course } \\
\text { for Development Oriented Research In Agriculture (ICRA) Indonesian Center for Environmental Law (ICEL) }\end{array}$ \\
\hline Major Natural Resources & $\begin{array}{l}\text { The natural resources of Indonesia include petroleum, tin, natural gas, nickel, timber, bauxite copper, fertile soil, coal, } \\
\text { gold, and silver. In addition, there are vast rain forests, coral reefs and mangrove forests that serve as home to a large } \\
\text { variety of plants and animals. Indonesia is known for its Orangutans and Komodo Dragons. There are over } 40,000 \\
\text { species of plants and about } 6000 \text { species are used by natives in traditional rituals and for herbal medicine. }\end{array}$ \\
\hline $\begin{array}{l}\text { Major Environmental and } \\
\text { Conservation Issues }\end{array}$ & $\begin{array}{l}\text { Forest fires have often been started by plantation owners and the timber industry to clear forest for their activities. In } \\
\text { recent years they have burned out of control due to low rainfall and unusual wind patterns caused by El Nino They } \\
\text { cause transnational air pollution and destroy huge areas of forest habitat. } \\
\text { Indonesian fires blamed on plantations, ENN Daily News - 8-10-99 } \\
\text { ASEAN moves up smog meeting as fires rage, ENN Daily News -- 8-10-99 } \\
\text { Indonesia's Forest Fires Pose an Economic Threat } \\
\text { Also, there are problems due to commercial deforestation. Efforts are being made to preserve rare animals like the } \\
\text { Komodo Dragon. Recently, in } 1997 \text { a new species of coelacanth, a fish that was thought to be extinct for } 80 \text { million years, } \\
\text { was discovered by Mark Erdmann in Sulawesi. }\end{array}$ \\
\hline
\end{tabular}

Source: Page compiled by Kyle Lothringer as part of a class project in h90 "The Science of Biodiversity and Conservation" (Peter J. Bryant, Instructor), University of California, Irvine, Irvine, CA 92697, USA. 
and regulations by which the problems might be resolved (Owen, 1985). Ecology study structure and function of ecosystem. Principles of ecology, mention (1) The low of conservation of matter, although matter can be change from one form to another, it can neither be created nor destroyed by ordinary physical and chemical changes. Although energy cannot be converted and destroyed, it can be converted from one form to another; Matter and energy laws - Their ultimatum to spaceship earth, we cannot continue to act as if we rule nature, but we must act as though nature rules us; (2) Whenever energy is converted from one form to another, a certain amount is lost in the form of heat. Photosynthesis is the process by which green plant converts the raw materials carbon dioxide and water to glucose in the presence of sunlight. The green pigment in plant, known as chlorophyll, serves as catalyst in the process (Owen, 1985; Rasul, 2016). The government and some non government organizations were participated in conservation practice, were reported in Table 1 .

\section{Mineral and energy management}

Fossil fuels have become central to Indonesia's energy policy and its main source of export revenues. Growing environmental concerns, both domestically and internationally, combined with subsiding coal prices and the on-going shale gas revolution, call into question the sustainability of such a strategy. Indonesia should increase its energy efficiency and further develop gas to plug the gap until sufficient renewable energy, especially geothermal, comes on line. Government control over the oil industry via state-owned Pertamina should be gradually reduced. Clarifying, streamlining and publicising simple regulations in energy and minerals, especially regarding land rights and on-shore processing, and removing foreign-ownership restrictions will help bring much needed investment. The pressure on the environment that natural resource exploitation is creating should be addressed by increasing the share of gas and renewables in the energy mix, properly defining property rights and regulations regarding forest land, and implementing a positive implicit carbon price. More resources should be devoted to combating widespread illegal mining and deforestation (Dutu, 2015).

Indonesia possesses vast reserves of coal, mostly steam coal of medium calorific value used for energy production (and some small amounts of lower-end coking coal products). It also possesses huge reservoirs of natural gas and oil, and was until 2009 the only Asian country in the Organisation of Petroleum Exporting Countries (OPEG). In terms of minerals, Indonesia is the world's largest exporter of refined tin and (until recently) nickel ore, and a leading exporter of bauxite, lead, gold and copper. The Grasberg mine in
Papua has the world's third-largest copper reserves and the world's biggest gold reserves.

The Indonesian Government is also exploring alternative energy sources to reduce dependence on oil. The renewable energy sources can be defined as captured an energy resource and replaced rapidly by a natural process such as power generated from the sun or from the wind. Alternative energy sources, are gas, coal, hydropower, geothermal, and solar power (Rio, 2012). Nuclear fuel and waste cycle are also alternative energy. Though, their radioactive contamination of the human environment is most likely to occur during the transport of spent fuel for reprocessing and during the transport and disposal of nuclear waste (Owen, 1985). Government currently explore the alternative energy sources, such as biomass based energy or biofuel with ingredients such as oil palm plantation crops, sugarcane, cassava, and distance (Rio, 2012).

Natural resources management is one of the Indonesian development planning that alignment with Sustainable Development Goals program.

\section{Sustainable Development Goals (SDGs)}

The alignment of Indonesian development planning and SDGs, can be explained that Indonesia has four pillar development, i.e. environment, social, economic, law and governance. Management of natural resources, water security, soil and biodiversity conservation are part of environment goals. For mainstreaming of SDGs into National Development Agenda were implemented through three steps, were (1) SDGs Roadmap as planning document of strategic steps to achieve SDGs 2016-2030, (2) National Action Plan as planning document to achieve SDGs for National Level, (3) Preparing Planning Document to achieve SDGs for Sub-national Level (Yusuf, 2016).

Indonesia is highly committed to implement SDGs. The substance and objective of SDGs (Dinpanah and Lashgarara, 2008; Bich et al., 2020; Shubhra and Palwal, 2019) are in line with "Nawacita" (Indonesia's national development vision), National Long Term Development Plan (RPJPN) 2005-2025 and the National Medium-Term Development Plan (RPJMN) 2015-2019. The same commitment to jointly implement SDGs by all countries in the world is essential to eradicate poverty, promote shared prosperity and improve environmental quality. Issues of poverty, welfare, and environmental quality are common challenges to be faced globally as one planet. Therefore, one of the main necessary conditions to achieve SDGs is an enabling situation that should be created jointly: a global peace, security and stability. Goals, targets, and indicators of SDGs that have been agreed are continuation and expansion of Millennium Development Goals (MDGs) that were implemented in 2000-2015. Indonesia is also highly committed to the 2017 VNR. The theme of 2017 VNR is "Eradicating 
poverty and promoting prosperity in a changing world". In preparing the VNR, all of the four participation platforms are involved, i.e, government (Minister of National Development Planning, 2017), civil society organizations (Starbird et al., 2016), philantrophy and business society (Sahaa et al., 2018; Lal, 2020), academics and experts (Keesstra et al., 2016; Xiao et al., 2018). To meet the Sustainable Development Goals, the Increasing distribution and connectivity of other regions are one of the Indonesian government programme. The government, aware of each region's potential and comparative advantages, has put connectivity and specialisation to manage natural resources at the heart of the Master Plan for Acceleration and Expansion of Indonesia's Economic Development 2011-2025 (Dutu, 2015).

Although the government has already implemented implemented SDGs to national program; however, some new strategy requires to be implemented to 'localize' the global goals, i.e. (1) optimizing the current technocratic framework of SDGs implementation; (2) establishing guidelines for a sustainable development framework at provincial and district/city level; (3) incorporating insights from civil society, industry, and a range of non-state actors who work on sustainability, establishing a forum for their participation in the SDGs implementation processes; and (4) establishing a policy network to measure the implementation of the SDGs at the national and subnational levels by incorporating the insights of non-state actors (Agussalim et al., 2019). Main challenges of implementing SDGs, are (1) Involvement of all parties in a process to establish mutual trust, (2) Developing database system for aligned indicators as well as indicators that will be developed, (3) Disaggregating of the 241 SDGs indicators by gender, age group, geographic location, income level, disability, and migration status (Yusuf, 2016).

\section{GONGLUSION}

The Indonesian government has implemented the natural resources management planning that alignment with SDGs programme, through (1) integrated water resources management program to store water during the rainy season and serve water during the dry season; (2) afforestation programme to prevent runoff, sedimentation and soil erosion; (3) agroforestry and forest management that always consider of ecological, social, and legal factors; (4) a guide for sustainable management of Indonesia's biodiversity was mentioned in Indonesia Biodiversity Action Plan (IBSAB); (5) the government and non-government organizations participated in conservation practice; (6) exploring alternative energy sources to reduce dependence on oil, such as biomass based energy or biofuel with ingredients of oil palm plantation crops mainstreaming of SDGs into National Development agenda based on SDGs Roadmap, National Action Plan as planning, and SDGs program for Sub-national level. This program was participated by all stakeholders included government, civil society organizations, philanthropy and business society, academics and experts. Though the government has already implemented SDGs program, but innovative strategic need to be developed.

\section{ACKNOWLEDGEMENTS}

My gratitude goes to the Head of Research Center for Biology, the Indonesian Institute of Sciences, Cibinong Science Center, Cibinong of West Java, Indonesia for her support and assisntance during the preparation of the manuscript.

\section{REFERENCES}

Agussalim, D., Ahmad Rizky, Umar, A.M., Larasati, K. and Tobing, D.H. (2019). Localizing the Sustainable Development Goals: Assessing Indonesia's Compliance towards the Global Goals

Researchgate. Preprint. June 2019: 39-62. DOI: 10.1163/9789004391949_003.

https://www.researchgate.net/publication/333774235.

Bich, T.T.N., Yi-Ching, G., Tri, D.Q., and H.D. Khoa (2020). Applied aquaponics to culture high value local species and ultimately reused and recycle the local materials to build the green and sustainable agriculture. International Conference on Resources and Environmental Research 2019, IOP Conf. Series: Earth and Environmental Science IOP Conf. Series: Earth and Environmental Science 432 (2020) 012008 IOP Publishing doi:10.1088/1755-1315/432/1/012008.

Bryant, P.J. (2020). The Science of Biodiversity and Conservation, University of California, Irvine, Irvine, CA 92697, USA.

Dinpanah, G. and F. Lashgarara (2008). Designing an Optimum Model for Protection and Improvement of Sustainability of Natural Resources and Environment in Iran. Ann. N.Y. Acad. Sci. 1140: 60-67 (2008). G_ 2008 New York Academy of Sciences. doi: 10.1196/annals.1454.029

Dutu, R. (2015). Making the most of natural resources in Indonesia. OEDG Economics Department Working Papers No. 1236, 28-May-2015.

https://dx.doi.org/10.1787/5js0cqqk42ls-en.

Fulazzaky, M.A. (2014). Challenges of Integrated Water Resources Management in Indonesia. Water (6), 2000-2020; doi:10.3390/w6072000

Hidayat, A. (2009). Indonesian Land Resources: Potency, Problems, And Utilization Strategy. Jurnal Sumberdaya Lahan (3) 2: 107-117. ISSN 1907-0799. 
ICAR (2020). Renewable Energy e-course of ICAR. www.agrimoon.com.

Conservation International Indonesia https://www.conservation.org/places/indonesia.

$(2020)$

Ja"germeyr, J., Pastor, A., Biemans, H. and D. Gerten. (2017). Reconciling irrigated food production with environmental flows for Sustainable Development Goals implementation. Nature Communications. DOI: 10.1038/ncomms15900. Nat. commun. (8): 1-9.

Keesstra, S.D., Bouma, J., Wallinga, J., Tittonell, P., Smith, P., Cerdà, A., Montanarella, L., Quinton, J.N., Pachepsky, Y., Wim H. van der Putten, Bardgett, R.D., Moolenaar, S., Mol, G., Jansen, B. and O.L.O. Fresco (2016). The significance of soils and soil science towards realization of the United Nations Sustainable Development Goals. Soil (2): $111-128$

www.soil-journal.net/2/111/2016/doi:10.5194/soil-2-1112016 (C) Author(s) 2016. GC Attribution 3.0 License.

Lal, B.S. (2020). A Review of understanding sustainable sanitation. International fournal $f$ or Innovative Research in Multidisciplinary Field. 6 (5): 358-385., ISSN: 2455-0620, Available online on - www.ijirmf.com.

Minister of National Development Planning (2017). Head of National Development Planning Agency. Republic of Indonesia Voluntary National Review (VNR) 'Eradicating Poverty and Promoting Prosperity in a Changing World.

Nalang, V.S. (2003). Indonesian Biodiversity And Action Plan 2003-2020. Head Division For Biodiversity Conservation Instruments, Ministry of Environment.

Nalang, V.S. (2009). Mainstreaming Biodiversity into national, local and sectoral policies and programmes Indonesia. Ministry of Environment Montreal, 13-15 May 2009.

Owen, O. (1985). Natural Resources Conservation, An Ecological Approach. Macmillan Publishing Company, New York.

Phelps, J., Hariyanti, B., Sinaga, A.C., and A. Dermawan (2014). Environmental Valuation in Indonesia Implication for forest policy, legal liability and state losses estimates. CIFOR. Brief, 31 October 2014. cifor.org.

Rasul, G. (2016). Managing the food, water, and energy nexus for achieving the Sustainable Development Goals in South Asia. Environmental Development. journal homepage: wrere.elsevier.com/locate/envdev Science Direct, Elsevier (18): 14-25.

Rio (2012). Natural Resources Indonesia, January 11, 2012, About of indonesia.blogspot.com/2012/01/natural-resources.

Sahaa, R., Deya, N.C., Rahman, S., Galagedarac, L. and P. Bhattacharyad (2018). Exploring suitable sites for installing safe drinking water wells in coastal Bangladesh. Groundwater for Sustainable Development 7: 91-100. journal homepage: www.elsevier.com/locate/gsd. Contents lists available at ScienceDirect, Elsevier

Sawe, B.E. (2018). What are the major natural resources of Indonesia?. World Atlas, Oct. 19, 2018, worldatlas.com/articles/what-are-the-major-natural-resourc es-of-indonesia.html.

Shubhra and Palwal (2019). Green Chemistry: A Roadmap for Sustainable Agricultre in India. International fournal of Multidisciplinary Educational Research Volume 8, Issue 5(2):124-131. ISSN: 2277-7881. Published by Sucharitha Publications 48-12-3/7, Website: www.ijmer.in.

Starbird, E., Norton, M. and R. Marcusa (2016). Investing in Family Planning: Key to Achieving the Sustainable Development Goals. Global Health: Science and Practice (4)2: 191-210.

van Dijk, A.I.J.M.., Bruijnzeel, L.A., and Purwanto, E. (2004). Soil Conservation In Upland Java, Indonesia: Past Failures, Recent Findings And Future Prospects. Isco 2004 13th International Soil Conservation Organisation Conference - Brisbane, July 2004, Conserving Soil And Water For Society: Sharing Solutions. 6p.

Waldron, A., Garrity, D., Malhi, Y., Girardin, C., Miller, D.C. and N. Seddon (2017). Agroforestry Can Enhance Food Security While Meeting Other Sustainable Development Goals. Tropical Conservation Science DOI: 10.1177/1940082917720667 journals.sagepub.com/home/trc, Special Issue: Commercial Agriculture in Tropical Environments. (10): $1-6$.

WGED (1987). Our common future. Oxford: Oxford University Press for the World Commission on Environment and Development.

World Water Council (2003). Water Resources Management Towards Enhancement of Effective Water Governance in Indonesia. Ministry of Settlements and Regional Infrastructure, Directorate General of Water Resources, Republic of Indonesia. For The 3rd World Water Forum KyotoJapan, March 2003.ISBN: 92-95017-03-X.

Xiao, W., Mills, J., Guidi, G., Rodríguez-Gonzálvez, P., Barsanti, S.G. and D. González-Aguilera (2018). Geoinformatics for the conservation and promotion of cultural heritage in support of the UN Sustainable Development Goals. ISPRS Fournal of Photogrammetry and Remote Sensing 142: 389-406. Contents lists available at ScienceDirect. Elsevier. journal homepage: www.elsevier.com/ locate/ isprsjprs.

Yusuf, G. (2016). Integrating SDGs to Development Plan. Deputy Minister for Maritime and Natural Resources. Thailand Meeting, Bangkok, 24-25 Oktober 2016. 